\title{
SOB O VERMELHO DOS CRAVOS DE ABRIL - LITERATURA E REVOLUÇÃO NO PORTUGAL CONTEMPORÂNEO
} Under the red of the carnations of Aprilliterature and revolution in contemporary Portugal

\section{Gerson Luiz Roani*}

\author{
Ora passou-se porém \\ Que dentro de um povo escravo \\ Alguém que lhe queria bem \\ Um dia plantou um cravo. \\ Era a semente da esperança \\ Feita de força e vontade \\ Era ainda uma criança \\ Mas já era liberdade.
}

José Carlos Ary dos Santos, Obra poética.

Aqui/do silêncio das gavetas/da pátria amordaçada/ dos peitos desfeitos pelas torturas da pidel subiu o clamor da liberdade/ floriu abril."*

* Universidade Regional Integrada do Alto Uruguai e das Missões.

** Inscrição colocada, em 1984, no Aljube, edifício onde eram detidos os presos durante as preliminares dos processos criminais contra o regime salazarista. Esse edifício encontra-se na rua de Augusto Rosa, nas proximidades da Sé de Lisboa. 
A s "revoluções", sejam elas artísticas, sociais, religiosas e políticas, têm se caracterizado, ao longo de toda a história humana, por deixarem, atrás de si, rastros transformadores de variada ordem, alcance e intensidade. Nessa direção, a Revolução dos Cravos, em 1974 representa, depois da instalação da República, em 1910, o segundo acontecimento mais importante da História portuguesa do século XX e, talvez, um dos mais importantes de todo o processo histórico português, por causa dos desdobramentos e caminhos que ela suscitou e tem, ainda hoje, originado.

Como acontecimento histórico, o 25 de abril transformou a vida de todos os portugueses, modificando as instituições sociais e, sobretudo, influenciando o âmbito artístico lusitano. A abordagem da produção literária portuguesa destes últimos 30 anos não pode prescindir de sondar o modo como esse acontecimento histórico influenciou a atividade escritural dos autores lusitanos. Essa sondagem mostra-se instigante, no caso da ficção portuguesa contemporânea, pois pode ser demonstrada uma estreita vinculação das alterações sociais com a renovação do próprio percurso artístico dos escritores portugueses anteriores e subseqüentes a 1974. A anulação das amarras impostas à atividade artística implicou em uma nova organização editorial, no apoio das novas entidades públicas à produção artística, na implantação de prêmios literários e, principalmente, na livre manifestação dos autores, anteriormente silenciados pelo antigo regime. Acerca dessas transformações recaídas sobre a Literatura Portuguesa contemporânea das duas últimas décadas, Carlos Reis escreveu o que segue:

O olhar que hoje podemos lançar sobre a ficção portuguesa posterior a 1974 há-de ter em conta necessariamente a projecção sobre essa ficção de tudo o que uma brusca mutação política implica e, no seu contexto, as conseqüências arrastadas pela supressão dos mecanismos repressivos que impediam sobre a criação literária. ${ }^{1}$

Com propriedade, o teórico português explora a íntima vinculação existente entre as transformações político-sociais ocorridas em Portugal, no ano de 1974, e a

1 REIS, Carlos. Romance e história depois da revolução - José Saramago e a ficção portuguesa contemporânea. In: ENCONTRO DE PROFESSORES UNIVERSITÁRIOS BRASILEIROS DE LITERATURA PORTUGUESA, 16, Porto Alegre. Anais... Porto Alegre: EDIPUCRS, 1994. p.169. 
novíssima ficção lusitana das últimas duas décadas. Obviamente, poder-se-ia estabelecer uma relação estreita de causa e efeito entre o novo cenário político e as obras surgidas, posteriormente, sob tal influxo. Todavia, o estabelecimento dessa relação imediata traz no seu núcleo a exclusão de outros fatores, inclusive anteriores à Revolução, responsáveis pela pluralidade de vias ficcionais assumidas pelo romance português pós-revolução. O excerto de Carlos Reis incide sobre a produção literária contemporânea. Todavia, isso não reduz a Literatura Portuguesa contemporânea a uma mera conseqüência das mudanças políticas ocorridas sob a atmosfera libertária da Revolução. Devemos ter em mente que, se a Literatura Portuguesa atual vive um período de efervescência, tal processo é tributário das tentativas de inúmeros romancistas de todo o século $\mathrm{XX}$ português, os quais pretenderam alcançar na prosa de ficção uma expressão genuinamente lusitana. Esse esforço orientou a produção ficcional e crítica dos autores do Neo-realismo e de muitos escritores das décadas de cinqüenta e sessenta. Todavia, é inegável que esse esforço foi intensificado, tanto qualitativa, quanto quantitativamente, com a eliminação dos mecanismos repressores que coibiam a produção artística lusitana.

A Revolução dos Cravos foi contada/cantada por inúmeros tipos de textos que se configuram como testemunhos dos desdobramentos do acontecimento de abril. Jornais, revistas, livros de testemunhos e obras historiográficas procuraram descrever e, também, entender a dinâmica do processo libertário que desalojou do poder uma ditadura de quatro décadas, promovendo a abertura democrática.

Em meio a essa ampla gama de textos sobre tal acontecimento, a Literatura sob as formas da lírica, do romance e da dramaturgia transfigurou, na plenitude de suas modalidades discursivas, esse delicado momento da recente História Portuguesa. Cumpre mencionar que a arte literária não se limitou a realizar a mera representação da revolução como evento transformador da sociedade portuguesa. O universo literário captou, no advento desse novo tempo, a necessidade de repensar os caminhos da expressão literária portuguesa, sobre a qual havia pairado, durante quase meio século, o crivo de uma censura impiedosa e limitadora da livre expressão artística. Ora, a desmistificação das amarras colocadas pela política salazarista ao labor escritural de gerações de artistas ocasionou o empenho dos escritores lusos, quando da derrocada do sistema repressivo, na realização de um compromisso revolucionário atingindo as formas discursivas, os temas e as novas perspectivas criativas descortinadas pela eliminação dos entraves impostos pela ditadura à atividade artística. Na sua originalidade, na profundidade da sua percepção da realidade, na visão privilegiada do autor, o texto ficcional pode levar a intuir a significação de um momento histórico. Esta face da atividade do escritor e do seu produto, o texto literário, fica mais evidente num regime de força, no qual a censura e o terror pairam ameaçadores sobre o processo livre da comunicação. 
Essa problemática exige o retroceder a esse tempo anterior à Revolução, sob o império da censura. De 1926 até 1974, o destino das produções literárias, em Portugal, pode ser entendido a partir de três condições envolvendo as obras produzidas. Estas podiam ser toleradas, proibidas ou mutiladas, dependendo do arbítrio dos censores. $\mathrm{O}$ ato criativo via-se limitado, pois os artistas eram obrigados a ter diante de si a consciência de que seu trabalho artístico e o seu destino como escritores dependia daquelas pessoas encarregadas de analisar o produto final da sua escrita: a obra destinada à publicação. Sob esse crivo humilhante passaram escritores como Aquilino Ribeiro, Fernando Pessoa, Vergílio Ferreira, Agustina Bessa-Luís, José Régio, António Sérgio, Maria Teresa Horta, José Cardoso Pires, Agostinho da Silva, Irene Lisboa, Fernando Namora, Maria Judite de Carvalho, Isabel da Nóbrega, Urbano Tavares Rodrigues, Jorge de Sena, Isabel Barreno, Miguel Torga, Alves Redol, Sophia de Mello Breyner Andresen, entre outros.

Se não bastasse a censura estabelecida pela ditadura, todo escritor colocava diante de si o censor imaginário que condicionava e coibia a liberdade criativa. Esse procedimento angustioso sintomatiza o temor não do que a censura proibia, mas do que ela poderia proibir, quando a obra fosse posta ao obrigatório julgamento prévio. A censura intimidava os intelectuais e a sociedade, disseminando o medo sobre as possíveis conseqüências de qualquer ato reprovável à política oficial. Era o recurso ao “medo”, do qual falou José Régio com ironia:

O medo é que guarda a vinha diz-se. Em grande parte, tem sido o medo que tem guardado a actual situação. Pode, ainda, ser o medo quem melhor a defenda. Não só em Portugal como em quaisquer países onde um regime conquista o poder pela força, e pela força impera, esse poderoso inimigo da alma se agigantou a ponto de tapar todo o horizonte. ${ }^{2}$

"O medo é que guarda a vinha", escreve José Régio, evidenciando a apreensão a cercar a produção escritural portuguesa. Os escritores não sabiam quando uma obra podia ser proibida, ou mesmo destruída pela censura, sob os mais diversos e banais pretextos. A publicação de obras e de representações teatrais deveria ter o aval dos censores. Uma prática corrente era a apreensão e destruição de livros,

2 RÉGIO, José apud AZEVEDO, Cândido de. Mutiladas e proibidas. Para a história da censura literária em Portugal nos tempos do Estado Novo. Lisboa: Caminho, 1997. p. 14. 
vitimando os autores e as editoras. Esta realidade infame marcou quase meio século do panorama literário português. Escrever significava predispor-se a enfrentar condições muito penosas. A ação da censura aprofundou o isolamento dos escritores, chegando ao absurdo de agir sobre o escritor, enquanto indivíduo, e não sobre o texto produzido. A instituição censorial e o regime político que garantia a sua sustentação recorreram, variadas vezes, às medidas repressivas extremas, como a prisão de escritores, críticos literários, jornalistas e professores universitários. Sobre essas sombras a envolver a criação artística, registrou José Cardoso Pires, a quem, como se sabe, a censura não conseguiu limitar ou anular o poder de fabulação artística, revelado em suas engenhosas narrativas:

Entrava no detalhe individual, no pormenor privado e na provocação psicológica, de modo a condicionar o escritor e a impor-lhe o isolamento. A publicação de uma fotografia, a simples referência do seu nome em qualquer noticiário era cuidadosamente meditada. À crítica desfavorável à obra do escritor maldito, o Gabinete da Censura dava-lhe curso livre. À que o elogiasse punha-lhe o carimbo da proibição. Inversamente, ao literato de confiança deixava passar o elogio e cortava o pormenor negativo - e assim, dicotomizando, distorcendo, a censura impunha uma "imagem oficial" do escritor e redigia, ela também, uma versão apócrifa da Literatura portuguesa. ${ }^{3}$

Nunca será possível investigar o alcance e os efeitos da ação da censura portuguesa, no que diz respeito à criatividade dos escritores e pensadores portugueses, ao longo de meio século de existência do Estado-Novo. Todavia, esse panorama de limitações e repressões oferece vias para o entendimento da renovação literária portuguesa em todos os gêneros discursivos e do novo país que a revolução de 74 mostrou e forjou. Esse retrocesso, explorando, brevemente, os meandros da censura salazarista, evidencia a Literatura Portuguesa tentando superá-la, durante quase cinqüenta anos de História Portuguesa, denunciando as contradições da vida social portuguesa, por intermédio de uma linguagem velada, artificiosa e alegórica.

3 PIRES, apud AZEVEDO, op. cit., p. 22. 
Se, por um lado, é visível a efervescência criadora da Literatura Portuguesa atual, personificada pelo aparecimento de novos nomes artísticos no cenário literário lusitano, por outro lado, não deve ser olvidado que, junto com esses talentos recentes, aparecidos após o 25 de abril, despontam também os escritores mais antigos, cujas obras expressam a continuidade das produções desenvolvidas nas décadas anteriores, marcadas pelo confronto e pelas tentativas de sobrepor a criatividade ficcional à repressão ditatorial.

O advento de um novo tempo ficcional possibilitou a emergência de realizações ficcionais inéditas, muitas das quais impedidas de vir à luz pelos mecanismos da censura. A abertura democrática revelou autores fecundos, os quais o estado salazarista procurou calar ou submeter às diretrizes ideológicas do regime institucionalizado.

Ingenuamente, poder-se-ia pensar que a produção literária das gerações anteriores a 74 teria sido empreendida sob a égide de uma aparente "liberalidade" do regime. Acerca disso, cumpre registrar que as gerações anteriores não se mostraram colaboracionistas com as propostas políticas do Estado Novo salazarista. Em suas obras, ansiaram por uma real restituição das liberdades individuais e políticas. Os autores dessas gerações lançaram, ainda, as bases estéticas para a renovação literária ocorrida nas décadas de setenta, oitenta e noventa, sob o signo da abertura política, cultural e de integração com a nova Europa.

Estas gerações demonstram o empenho da palavra artística de sobrepor-se, pelo velamento metafórico discursivo, às limitações claras ou às artimanhas silenciosas que a máquina repressiva impunha à atividade artística. Isso reitera a veracidade de que a Literatura, quando bem dita, ultrapassa, em qualquer tempo e lugar, o abismo que separa o desejo individual e a opressão institucionalizada.

Inúmeras obras portuguesas, anteriores ou posteriores à Revolução dos Cravos, podem ser lidas sob o prisma da liberdade seqüestrada, a qual ganhou inúmeras expressões simbólicas na poesia, nas formas narrativas e na dramaturgia. Se durante quarenta anos a ideologia totalitária do salazarismo expandiu seus tentáculos opressivos por todos os setores da realidade portuguesa, a Ficção recusou o peso dessas limitações, violentando e denunciando os mecanismos opressores, através da criação de um discurso velado, mas nem por isso menos eficiente do que a denúncia aberta e destemida. Tal discurso, além de garantir a sobrevivência da atividade escritural, era a metáfora desse tempo de trevas vivido por todos os que estavam envolvidos com a prática literária: autores, leitores, críticos literários, teóricos da literatura e editores. Durante quase meio século, a ideologia salazarista aprimorou o seu arsenal repressivo, tentando neutralizar aquela atividade escritural que não partilhava do caráter corporativo e unificador do Estado Novo, mas advogava a liberdade de pensamento e de ação em todas as esferas e setores da vida lusitana. 
A Literatura Portuguesa desse período esmerou-se por enxergar e revelar, para leitores atentos e conscientes, pedaços de verdade nos absurdos da patética experiência fascista lusitana. De Miguel Torga a Alves Redol, de Agustina BessaLuís aos fragmentários textos de um Almeida Faria, de um Fernando Namora a um José Cardoso Pires, a ficção portuguesa examinou a tragédia recaída sobre Portugal, com a implantação do Estado Novo. Em suas páginas, os autores denunciaram a separação entre a sociedade portuguesa e o ideal social estabelecido pelo regime dominante, caracterizando a experiência num mundo em que a dominação ideológica procurava fazer de todos, indistintamente, prisioneiros. Paradoxalmente, nesse período impregnado de exclusão, de repressão, torturas e censura, a Literatura Portuguesa, contemplada em suas várias gerações até a recente produção artística nascida sob o influxo do vermelho dos cravos de 74, impugnou os obstáculos impostos, magistralmente, nas imagens da ficção.

A mirada sobre esse percurso escritural da Literatura Portuguesa revela, na base da reflexão de Eduardo Lourenço, que os processos de repressão, bem como as revoluções, que os eliminam, estimulam o imaginário coletivo, no qual a repressão e o subseqüente processo revolucionário ocorrem. ${ }^{4} \mathrm{~A}$ constatação do filósofo português aponta para a singularidade da revolução portuguesa. Com o seu advento, Portugal passou a viver em uma espécie de embriaguez, pois todas as expectativas e esperanças do porvir lusitano foram depositadas no desdobramento do processo libertário.

Esse momento de fulgor representou uma metamorfose radical de todas as instituições portuguesas. No que tange à Literatura, os três anos que imediatamente sucederam a revolução caracterizaram-se por um silêncio que não significou indiferença, mas cautela, quanto aos rumos do processo deflagrado em abril de 74 . Essa cautela pode ser entendida pela ausência de publicação de obras expressivas, nesses anos. Nesse horizonte, poder-se-ia argumentar que tal carência vinculava-se à atuação persecutória da censura. Com a eliminação dos entraves utilizados para coibir a publicação literária, deveriam ter aparecido, rapidamente, as "obras engavetadas", esquecidas ou proibidas pela ditadura. Entretanto, não foi isso que aconteceu, pois como escreve Lourenço, "a Revolução de Abril, para aquelas gerações, que durante décadas, de modos diversos, a haviam sonhado, chegava, enquanto acontecimento libertador de pulsões criadoras, realmente tarde". ${ }^{5}$

4 Cf. LOURENÇO, Eduardo. Literatura e revolução. In: O canto do signo. Existência e Literatura (1957-1993). Lisboa: Presença, 1994. p. 292-301.

5 Ibid., p. 293. 
O que se vislumbra através dessa constatação de Lourenço? O pensador detectou que, para a maioria dos autores lusitanos, o processo revolucionário não alterou, substancialmente, os seus projetos artísticos específicos, os quais já vinham sendo empreendidos antes da liberdade oficial.

Que projetos artísticos são esses? Os daqueles autores já conhecidos e lidos, antes do 25 de abril, apesar das limitações políticas. Nesse momento, em que o povo português vivenciava a troca de uma ordem nefasta por outra democrática, $o$ momento revolucionário não lhes alterou as cosmovisões artísticas, no que diz respeito às formas, às temáticas e às reflexões acerca do literário, evidenciadas em suas escritas. Para autores com um lugar garantido no âmbito da Literatura Portuguesa da época, tais como Fernando Namora, Vergílio Ferreira, Augusto Abelaira, Maria Velho da Costa, Agustina Bessa Luís, Nuno Bragança, José Cardoso Pires e Almeida Faria, a revolução significou um momento de expectativa, de espera atenta e, mais ainda, de amadurecimento do que já estava sendo empreendido.

Claro está que, no momento mesmo em que a revolução transcorre e se consolida, apareceram obras de qualidade literária duvidosa, marcadas por uma grandiloqüente e panfletária exaltação do novo tempo português. Essas obras refletem os desdobramentos da revolução e não conseguiram elevar-se acima da mera representação factual, incapazes de revelar qualidade estética. O surgimento desse tipo de produção ficcional é natural no âmbito artístico pois,

Entre a realidade sócio-histórica e os seus reflexos artísticos há uma indispensável relação, mas o itinerário desta relação nunca é linear. O caminho artístico não acerta maquinalmente o passo pelo processo social; às vezes precede-o, outras afasta-se delee raramente coincide em pontos essenciais. ${ }^{6}$

Seja como for, a revolução instaurou o desafio. Qualquer que fosse o caminho trilhado por ela, haveria para a cultura portuguesa um antes e um depois de abril. No caso dos escritores antigos e dos novos, a situação criada pela liberdade exigia a continuidade da atividade escritural. Essa idéia de continuidade desmistifica a idéia de fronteira temporal estabelecida com a abertura de 74 em relação ao período literário precedente. $\mathrm{O}$ ingresso em um novo tempo da História Portuguesa não

6 EMINESCU, Roxana. Novas coordenadas no romance português. Lisboa: ICALP, 1983. p. $12-13$. 
significa, no caso da Literatura, rompimento abrupto e definitivo com as produções literárias passadas. A “fronteira temporal” não é inexpugnável, mas maleável às trocas e às reflexões sobre a produção ficcional portuguesa no período anterior e na fase pós-revolução. Segundo Roxana Eminescu, o novo cenário ficcional português estabelece em relação ao passado uma fronteira temporal que funciona como um:

...nexo, pois o novo nasce do velho, o que tomou hoje a forma dum núcleo, ontem, ou ante-ontem ainda não passava duma sombra. Os escritores de hoje não nasceram ex-nihilo, vêm de longe, dos anos passados, do tempo remoto de toda a literatura. Assim, referidas ou aludidas, obras anteriores a esse ano constituem o pano de fundo obrigatório do discurso sobre o romance português atual. (...) Reatar o fio a partir de 1974 significa, de facto, que vai tratar-se dos elementos estruturais da narrativa portuguesa que tomaram relevo, que se tornaram privilegiados, nos últimos anos, aproximadamente. ${ }^{7}$

O fragmento da lusitanista romena destaca a idéia de um continuum, a fim de caracterizar a ficção portuguesa contemporânea. O fluxo criador da atualidade não anula os projetos literários elaborados no período anterior à revolução, além de determinar que as circunstâncias e sendas políticas não foram as únicas responsáveis pelo novo cenário literário português. ${ }^{8}$

Essa continuidade é sintomatizada por criações que passam a explorar os infernos do pesadelo extinto com as suas limitações, interdições, censura, guerras africanas, exílio e imigração forçada. Como se vê, os temas veiculados pelo lavor artístico espelham e reconstituem as experiências vividas pelos escritores e pela população portuguesa, cuja livre expressão era impensável no período de trevas. Esses novos artifícios ficcionais suprem a falta de um tipo de exercício escritural que, durante a ditadura, era inviável ou que era empreendido sob o signo do hermetismo e da linguagem alegórica. Acerca desse novo panorama criativo, o diagnóstico de Eduardo Lourenço expressa que

7 Ibid., p. 10-11.

8 O estudo de Roxana Eminescu surge na seqüência do importante estudo de MACHADO, Álvaro Manuel. A novelística portuguesa contemporânea. Lisboa: ICALP, 1977. 95 p. Nesse livro, Machado estudou a produção romanesca lusitana dos anos trinta até a década de setenta. Quando Eminescu se refere ao conceito de "contemporâneo", ela tem em vista as obras escritas entre 1974 e 1984. No mapeamento feito pela autora, escapam os escritores novíssimos, entre eles, José Saramago. 
A importância do momento revolucionário, após o vazio imaginante natural dos começos, foi a de descobrir diante de todos - velhos ou novos autores, um espaço, aberto um horizonte efetivamente liberto, com a sua angústia necessária, com o seu desafio em termos não codificados como os do jogo conhecido da antiga atmosfera. ${ }^{9}$

O comentário de Eduardo Lourenço focaliza as circunstâncias em que os escritores portugueses encontraram-se envolvidos com as abruptas transformações políticas de 74. Como já vimos comentando, no que concerne à Literatura, essas mudanças implicaram na eliminação do entrave representado pela censura. A eliminação da prática censorial colocou os artistas literários diante de um horizonte efetivamente aberto. É essa abertura que trouxe no seu desenrolar a angústia acerca da execução artística de que nos fala Lourenço. Por que angústia, se a cultura portuguesa encontrava-se, agora, livre de amarras e de ameaças ao pleno e livre trabalho da Arte? Ora, se durante a repressão, os criadores obrigaram-se a lançar mão de uma linguagem cifrada, hermética e alegórica, projetando a Arte literária acima do âmbito medíocre e limitado que a política previa para ela, a Revolução estabelece a necessidade de "falar", em oposição ao silêncio castrador imposto anteriormente.

Assim, são criadas obras, nas quais são traduzidas as aventuras e desventuras coletivas e individuais das últimas décadas. Essas produções proporcionam, num momento inicial, um processo de redescoberta da sofrida realidade lusitana, de autoconhecimento coletivo, abrindo as possibilidades para a posterior revolução escritural, renovadora das formas e dos conteúdos, que teria lugar nas duas décadas subseqüentes. Oolhar atento sobre o desenrolar dessa ficção nos últimos anos constatará que poucas literaturas nacionais podem se orgulhar de um surto de engenhosa novidade tão intenso como o que se verifica na ficção portuguesa de hoje.

É neste cenário renovado, a partir de 1974 e no caudal de um processo de renovação ainda em curso, que certas presenças se impõem, em função da originalidade trazida pelas suas criações ficcionais. Nessa direção, é possível detectar algumas tendências recorrentes na ficção lusitana da atualidade.

Uma das tendências mais expressivas da nova ficção romanesca portuguesa pode ser identificada com um conjunto de obras cujos universos ficcionais são construídos mediante a tematização da sangrenta guerra colonial mantida por Portugal, na África, de 1961 até 1975, quando, por fim, os povos africanos

9 LOURENÇO, op. cit., p. 299. 
conquistam suas independências nacionais, após, pelo menos, três séculos de ininterrupta ocupação e exploração portuguesa. A crua representação dos acontecimentos relativos ao envolvimento de Portugal com as guerras pela descolonização africana, confere a tais narrativas traços de vigoroso imediatismo, pois transfiguram com uma veemência testemunhal, beirando a revolta, as ações colonialistas, violentas, preconceituosas e repressivas da política lusitana, não só em relação aos africanos insurrectos, mas também em relação ao próprio povo português, o qual arcou com imensas perdas financeiras e humanas, em nome de uma quimera imperial que as outras nações não reconheciam e condenavam. Essa política portuguesa em relação à África acentuou o isolamento português no cenário internacional, mas, paradoxalmente, forneceu ao arbitrário regime estabelecido no poder um dos seus esteios de sustentação, durante décadas. As circunstâncias históricas comprovavam que essa desgastada idéia de império não possuía mais qualquer razão de ser, pois nunca chegou a existir como assevera Eduardo Lourenço:

\begin{abstract}
Assim, nasceram e se desenharam sobre o rosto de uma África mais vaga do que a lua esses espaços compensatórios da pequenez metropolitana, espaços vividos e reais para os colonos, mas puramente fictícios, não só para o cidadão comum do Porto ou de Lisboa, como para muito dirigente, que do Terreiro do Paço os governava por telepatia. Em tempos de irrealismo histórico intenso como foram os do último regime, esta estranha relação entre Metrópole e pseudo-império, deu origem a uma das mais grotescas mitologias colonialistas de que há memória. ${ }^{10}$
\end{abstract}

A feição testemunhal dessas tessituras ficcionais não poderia ser revelada de outra forma, considerando-se que esses autores, revoltadamente, transfiguram, sob a ótica da reinvenção, as suas vivências pessoais de participantes efetivos desse processo sangrento que, no final do século XX, insistia na subjugação e restrição da liberdade das nações africanas de Língua Portuguesa. Os temas apontados como característicos desses textos aparecem nas ficções de um João de Mello, de um Fernando de Assis Pacheco, de um Cristóvão Aguiar e, sobretudo, nos romances do celebrado António Lobo Antunes, que tem feito do horror experimentado pelos portugueses, na África, um dos seus caminhos criativos prediletos.

10 LOURENÇO, Eduardo. "Réquiem" para um império que nunca existiu. In: O fascismo nunca existiu. Lisboa: Dom Quixote, 1976. p. 99. 
Os textos dos artistas citados reiteram que a História da Guerra Colonial Portuguesa está, ainda, para ser feita, pois o que os impulsiona a trilhar essas veredas temáticas é o fato de que Portugal não faz e não problematiza essa História e, até agora, tem feito tábua-rasa e pouca coisa tem sido dita e escrita. Sob esse prisma, haveria uma vontade intrínseca aos portugueses de não falarem da barbárie vivenciada em terras africanas. Em função desse silêncio, só a Ficção se aproximaria da realidade acontecida. O primeiro dos autores destacados, o açoriano João de Mello insiste na existência de um coeso grupo de escritores portugueses e africanos preocupados em recuperar a brutalidade desse passado afro-lusitano recente, que está mergulhado em um silêncio desolador, o qual impede a assunção de episódios sangrentos, figuras históricas e situações que, para benefício de uma consciência histórica madura e interventora precisam ser apontados e discutidos. ${ }^{11}$

Nesse cenário literário novíssimo, são narrativas revolucionárias, não só quanto à temática, mas, sobretudo, quanto à linguagem usada, as que exploram o campo da escritura feminina. A menção às autoras Maria Velho da Costa, Teolinda Gersão, Maria Gabriela Llansol, Eduarda Dionísio, Wanda Ramos, Luísa Costa Gomes, Olga Gonçalves, Lídia Jorge, Helena Marques, Clara Pinto Correia, Maria Ondina Braga, sublinha a preocupação com a engenhosidade discursiva, remetendo para uma inovação formal operadora de diluições na conformação habitual dos gêneros literários. A essa deliberada renovação formal, enlaça-se a emergência do feminino na ficção. As vozes emergentes destas produções revelam-se, assumidamente, femininas, traduzindo a revolta e a denúncia contra a globalidade de um sistema, no qual as mulheres figuraram num plano assinalado pela submissão. São criações exorcizadoras de um universo português masculino que, ao longo de oito longos séculos, condenou as mulheres à dor, à exclusão, à amargura, à violência e à desigualdade. Procura-se superar, através do "dizer-se" na escrita, tudo o que representou agressão e obstáculo à liberdade e ao salto criador da mulher, como voz de tonalidade autônoma e diferente em relação ao discurso codificado pelo homem. Discurso que não lhe serve, por não conseguir traduzir anseios, expectativas e uma peculiar visão das coisas, que só pelo feminino podem ser sentidos e, conseqüentemente, verbalizados.

As produções desses autores e autoras vinculados, respectivamente, à representação da Guerra Colonial Africana ou à sintomatização do universo feminino, apontam, ainda, a emergência de uma invariante nos horizontes criativos trilhados

11 Acerca dessa questão pode-se ler: MELLO, João de. Os anos da guerra, 1961 - 1975 - Os portugueses em África. Lisboa: Dom Quixote, 1988. (2 volumes). 
pelos escritores lusitanos: a presença ou a intenção de fazer a História, mediante a Ficção. Os criadores que aderem à exploração dessa invariante no âmbito ficcional fazem da História o traço estruturante dos seus projetos ficcionais.

Poderíamos, inclusive, ir mais longe e afirmar, sem receio de cair em erro, que é nessa presença da História, em termos de resgate, representação e problematização do passado português, que reside o mais expressivo "sintoma" da ficção portuguesa atual. ${ }^{12}$ Isso é facilmente constatável, quando considera-se, com a atenção que merecem, as obras de Almeida Faria, José Cardoso Pires, Mário Cláudio, Álvaro Guerra, Mário Ventura e, principalmente, José Saramago. Tais autores, bem como aqueles outros vinculados à Geração da Guerra colonial e ao campo da escritura feminina, investem na escrita de uma História transfigurada com vestes ficcionais, através do resgate dos episódios relativos à trajetória histórica portuguesa, ao longo de oito séculos de vida nacional. Essas produções são marcadas por uma acentuada vinculação à realidade social, cultural, histórica e ideológica portuguesa. Os romances surgidos sob o crivo desse desejo de revelação da História impõem ao leitor, sobretudo ao português, diretamente envolvido com a matéria histórica apontada, uma série de questões incontornáveis, as quais acabam por conferir à escrita romanesca nuances crítico-combativas. De acordo com Álvaro Cardoso Gomes, as narrativas portuguesas são combativas, pois revelam, de modo similar à ficção latino-americana, uma forte consciência dos problemas sociais, políticos e identitários de Portugal, enquanto processo histórico. ${ }^{13}$

Esse pendor crítico-combativo manifesta-se mediante questões subliminares despontadas na leitura desses romances: como explicar que de senhores do mundo, nós, portugueses, tornamo-nos uma nação pobre, humilhada e destinada a figurar como coadjuvante no certame dos demais povos? Como nos deixamos submeter, durante quase cinqüenta anos, por uma ditadura fascista, que nos impediu a livre e plena manifestação da vida? Como entender que, numa Europa civilizacionalmente avançada, sejamos um povo inculto, atrasado e sem tradição crítica, científica, filosófica e historiográfica de peso?

12 Cf. ROANI, Gerson Luiz. No limiar do texto: literatura e história em José Saramago. São Paulo: Annablume, 2002. Sobre essa questão ver ainda do mesmo autor: ROANI, Gerson Luiz. A história comanda o espetáculo do mundo: ficção, história e intertexto em O Ano da Morte de Ricardo Reis de José Saramago. Porto Alegre: PPG/LETRAS-UFRGS, 2002. 378 p. (Tese de doutorado em Literatura Comparada).

13 Cf. GOMES, Álvaro Cardoso. A voz itinerante. ensaio sobre o romance português contemporâneo. São Paulo: EDUSP, 1993. p. 83-84. 
Tais questões corporificam-se em romances reveladores de uma acentuada preocupação documental, fingindo ou tentando transfigurar ficcionalmente costumes, mentalidades, dados e acontecimentos que procuram criar no leitor a sensação de estar em contato com um discurso pautado por um "pacto de veracidade", como menciona Maria Lúcia Lepecki, ao estudar a narrativa lusitana atual. ${ }^{14}$ Por trás desse "pacto de veracidade", ou da incorporação da História, está o desejo de preencher falhas, vazios e silêncios, tornando a narrativa uma expressão de séculos de convulsões e modificações radicais na sociedade portuguesa. Assim, a arte do romance sob os mais diversos autores, estilos e posturas ideológicas exprimirá a intenção de traduzir todos os passos e descompassos da sociedade portuguesa. ${ }^{15}$

Essa transfiguração da matéria histórica por inúmeros romancistas portugueses geraria, como seria de supor, obras de nítida inclinação realista, pois, nelas, a linguagem se esforçaria para traduzir o mais fiel possível a realidade transtextual, no caso o universo dos fatos históricos, que lhe serviu de base e "presidiu" a confecção discursiva. Ora, esse efeito é só aparente, porque o resgate e a verbalização do real no terreno ficcional implica, aqui, o investimento na experimentação da linguagem artística, na inovação discursiva e na busca de novos caminhos e perspectivas para aquela escrita romanesca que percorre as sendas da História.

Esse investimento na experimentação escritural, na problematização acerca da representação do acontecimento histórico na malha ficcional de inúmeros romances portugueses deste final de século, condiciona e revela um outro traço recorrente na ficção portuguesa atual: a valorização da fabulação narrativa, da metaficcionalidade, da intertextualidade e do diálogo do sistema literário com outras áreas de conhecimento e outras artes. Essa dimensão inerente à construção do discurso ficcional é percebida por Maria Alzira Seixo nos seguintes termos:

...proceder a uma miscigenação de modos numa proposta de abertura descondicionada e indisciplinada que conduz a uma euforia de escrita muito produtiva mas de efeitos inevitavelmente desiguais. Adquire um peso teórico-prático impressionante a

14 Cf. LEPECKI, Maria Lúcia. O romance português na busca da história e da historicidade. In: Le roman portugais contemporain. Paris: Fondation Calouste Gulbenkian/Centre Culturel Portugais, 1984. p. 13-21.

15 Cf. GOMES, op. cit., p. 84. 
noção de "escrita", e como "textos" (encarados enquanto urdiduras de escrita) se consideram a maior parte das obras que então vem a lume. ${ }^{16}$

É inevitável, a partir da citação de Seixo, não pensarmos na recente Literatura Portuguesa como um texto infinito, amalgamador da tradição literária portuguesa do passado com a urgência e o dinamismo do espírito contemporâneo. Na esteira desse raciocínio, a Literatura Portuguesa contemporânea é vislumbrada como um terreno fértil de manifestações literárias, cujas diferentes nuances e tendências artísticas configuram-se como uma malha extensa, composta de diferentes intersecções, pontos e linhas. Essa imagem do sistema literário lusitano como uma ampla tessitura, lembra-nos a oportuna lição de Roland Barthes acerca das manifestações literárias e, particularmente, o efeito almejado pelo texto ficcional ao lançar teias, fios enredadores sobre o leitor:

Texto quer dizer Tecido; mas enquanto até aqui esse tecido foi sempre tomado por um produto, por um véu todo acabado, por trás do qual se mantém, mais ou menos oculto, o sentido (a verdade), nós acentuamos agora, no tecido, a idéia gerativa de que o texto se faz, se trabalha através de um entrelaçamento perpétuo; perdido neste tecido - nessa textura $-\mathrm{o}$ sujeito se desfaz nele... ${ }^{17}$

"O sujeito se desfaz no texto", escreve Barthes, discorrendo sobre a aliciadora sedução que a escrita literária instaura. Com base nisso, a aproximação ao âmbito literário português faz perceber que grande parte da sedução causada pelos textos portugueses provém do envolvimento, nem sempre fácil, do leitor com temas e argumentos de construção narrativa, oriundos da História lusitana, mas também, com uma variada gama de realizações textuais, integrando vários níveis de fabulação textual, fundindo gêneros, como a prosa e a poesia, multiplicando temas e situações, problematizando, ficcionalmente, a temporalidade e investindo, ainda, numa discursividade fantástica, maravilhosa e insólita, que não esconde a sua proximidade e afinidade com as melhores realizações da Literatura Latino-americana.

16 SEIXO, Maria Alzira. Ficção. Colóquio/Letras, Lisboa, n. 78, p. 32-42, mar. 1984.

17 BARTHES, Roland. O prazer do texto. São Paulo: Perspectiva, 1996. p. 83. 
Em A palavra do romance, Maria Alzira Seixo aprofundou esses aspectos das realizações escriturais lusas, unindo a textualidade à auto-referencialidade que a escritura romanesca passa a adotar, em Portugal, nas últimas décadas. ${ }^{18}$ Isto é, os romances adotam como traço distintivo a liberdade e a autonomia em relação a uma mimese estrita. Ou seja, nesse processo, o real é diluído e transformado em função da fabulação empreendida. Traços como a metaficcionalidade, o narcisismo da escrita, a autoconsciência discursiva, a valorização do jogo, além da intromissão de uma marcante e insinuante subjetividade minam ou corroem qualquer compromisso desses textos com uma mimese do real no sentido especular. A Ficção afirma-se como jogo, envolvendo o autor, o leitor e o universo que o presidiu. E se estamos falando dela como exercício lúdico, ela pode adotar uma independência mais ampla em relação ao real, subvertendo-o, modificando-o de acordo com as intencionalidades escriturais.

Em que consiste esse mostrar ou exibir a atividade enunciativa? Basicamente, que o discurso revela ou manifesta os seus próprios recursos expressivos e fabulatórios. No romance, as máximas possibilidades do código lingüístico são testadas, problematizadas e criticadas na busca do texto novo. Como escreve Manuel Gusmão, o discurso vislumbra a textualidade como "assunção plena da voz poética, como trabalho que mostra, inscreve, figura e diz, na obra, a enunciação poética que a constituiu". ${ }^{19}$

Essas tendências esboçadas acerca do romance português contemporâneo podem ser detectadas exemplarmente na obra de José Saramago. Sempre envolvido com a vida política de Portugal, após 1974, o romancista passa a se situar literariamente ao lado desses autores que vivenciaram a revolução e que procuram imprimir às suas obras um traço combativo, crítico, experimentalizante e reflexivo em relação à nova realidade portuguesa e aos novos caminhos abertos para a produção artística. Nas suas narrativas, percebe-se um empenhado trabalho de resgate e de problematização da matéria histórica pelo universo ficcional, mas, sobretudo, uma perspectiva irônica e subversiva em relação ao discurso literário, historiográfico e político. Na verdade, a obra saramaguiana reinventa a matéria histórica, não numa perspectiva nostálgica, mas de forma consciente e crítica. Em outras palavras, a interlocução entre a História e a Ficção promove a fusão da autoconsciência e da auto-reflexividade metaficcional com o aproveitamento de elementos do universo historiográfico.

18 Cf. SEIXO, Maria Alzira. Alteridade e auto-referencialidade no romance português de hoje. In:__ A palavra do romance: ensaios de genologia e análise. Lisboa: Livros Horizonte, 1986. p. 21-27.

19 GUSMÃO, Manuel. Linguagem e história segundo José Saramago. Vida Mundial, Lisboa, n.10, p. 12-15, nov. 1998. 
O romance consagra-se como o espaço da imaginação e da palavra, buscando apreender, na rapidez fulgurante do tempo, um rosto de Portugal que a Literatura e a História forjaram, ao longo dos tempos, mas que cabe ao texto novo revisitar e atualizar, como provocadora e instigante forma de repensar a identidade portuguesa e de projetar um futuro que, pela sua indefinição, é dramático e impronunciável.

\section{RESUMO}

Este artigo analisa alguns aspectos criativos do romance português contemporâneo, surgido após a Revolução dos Cravos de 1974. Com base nessa intenção, contata-se que há uma profunda vinculação entre as transformações políticas ocorridas em Portugal, após 1974, e a produção artística lusitana das últimas três décadas. Com a Revolução dos Cravos, a arte literária portuguesa empreendeu a revisitação crítica dos seus caminhos artísticos, sobre os quais havia pairado, durante meio século, a ação da censura salazarista. Com a liberdade, a Literatura Portuguesa passou a viver um período de notável efervescência criadora. No âmbito da produção narrativa, podem ser percebidas tendências marcantes do romance português, tais como a tematização da Guerra Colonial mantida por Portugal, na África, a emergência do feminino no campo da escritura literária e, sobretudo, a transfiguração e reescrita da História pela Literatura.

Palavras-chave: romance português, Revolução dos Cravos, História, censura, salazarismo.

\section{ABSTRACT}

This article analyzes some creative aspects of the contemporary Portuguese novel, came up after Clove Revolution in 1974. Based on that intention, it is verified that there is a profound link between political transformation occurred in Portugal after 1974 and artistic Portuguese production of the last three decades. With the Clove Revolution, Portuguese literary art undertook the critical revisit of its artistic pursuits, upon which had hovered during half century, the action of salazarist censorship. With liberation, Portuguese literature came to live a period of notable creative effervescence. In the ambit of narrative production, it can be noticed remarkable tendencies of the Portuguese novel, such as the theme of Colonial War kept by Portugal in Africa, the emergency of feminism in literature and, moreover, the transfiguration and rewriting of History through literature.

Key-words: Portuguese novel, Clove Revolution, History, censorship, salazarism. 
ROANI, G. L. Sob o vermelho dos cravos de abril...

\section{REFERÊNCIAS}

AZEVEDO, Cândido de. Mutiladas e proibidas: para a história da censura literária em Portugal nos tempos do Estado Novo. Lisboa: Caminho, 1997.

BARTHES, Roland. O prazer do texto. São Paulo: Perspectiva, 1996.

EMINESCU, Roxana. Novas coordenadas no romance português. Lisboa: Icalp, 1983.

GOMES, Álvaro Cardoso. A voz itinerante: ensaio sobre o romance português contemporâneo. São Paulo: Edusp, 1993.

GUSMÃO, Manuel. Linguagem e história segundo José Saramago. Vida Mundial, Lisboa, n. 10, p. 12-15, nov. 1998.

LEPECKI, Maria Lúcia. O romance português na busca da história e da historicidade. In: Le roman portugais contemporain. Paris: Fondation Calouste Gulbenkian/Centre Culturel Portugais, 1984, p. 13-21.

LOURENÇO, Eduardo. O canto do signo . Existência e Literatura (1957-1993). Lisboa: Presença, 1994.

Ofascismo nunca existiu. Lisboa: Dom Quixote, 1976.

MACHADO, Alvaro Manuel. A novelística portuguesa contemporânea. Lisboa: Icalp, 1977.

MELLO, João de. Os anos da guerra, 1961 - 1975 - Os portugueses em África. Lisboa: Dom Quixote, 1988.2v.

REIS, Carlos. Romance e história depois da revolução - José Saramago e a ficção portuguesa contemporânea. In: ENCONTRO DE PROFESSORES UNIVERSITÁRIOS BRASILEIROS DE LITERATURA PORTUGUESA, 16., Porto Alegre. Anais ... Porto Alegre: EDIPUCRS, 1994, p.169181.

ROANI, Gerson Luiz. No limiar do texto: literatura e história em José Saramago. São Paulo: Annablume, 2002.

- A história comanda o espetáculo do mundo: ficção, história e intertexto em $O$ ano da morte de Ricardo Reis de José Saramago. Porto Alegre, 2002.378 p. Tese (Doutorado em Literatura Comparada) - PPG/Letras, Universidade Federal do Rio Grande do Sul.

SANTOS, José Carlos Ary dos. Obra poética. Lisboa: Avante, 1975.

SEIXO, Maria Alzira. Ficção. Colóquio/Letras, Lisboa, n. 78, p. 32-42, mar. 1984. A palavra do romance: ensaios de genologia e análise. Lisboa: Livros Horizonte, 1986. 